\title{
Shell disease syndrome in the edible crab, Cancer pagurus - isolation, characterization and pathogenicity of chitinolytic bacteria
}

\author{
Claire L. Vogan, Carolina Costa-Ramos and Andrew F. Rowley
}

School of Biological Sciences, University of Wales Swansea, Singleton Park, Swansea SA2 8PP, UK
Author for correspondence: Andrew F. Rowley. Tel: +44 1792295455 . Fax: +44 1792295447. e-mail: a.f.rowley@swansea.ac.uk

Chitinolytic bacteria are believed to be the primary aetiological agents of shell disease syndrome in marine crustaceans. The disease principally results from the breakdown of their chitinous exoskeletons by the shell disease pathogens, but pathogenicity may also manifest internally should a breach of the carapace occur. The current study looks at the pathogenicity of a number of bacteria (predominantly from the genus Vibrio) isolated from the edible crab, Cancer pagurus. All chitinase-producing bacteria investigated were capable of growth in a minimal medium consisting of chitin powder from crab shells, but differed in their speed of growth and nature of chitinolytic activity, suggesting that they have different roles within the lesion community. Two isolates (designated 14 and 17 ) were chosen for studies on internal pathogenicity, which included the effect of the pathogen on crab tissues, the ability of the host to remove the bacteria from circulation and the antibacterial activity of crab blood. Initially, 14 was rapidly removed from circulation, but began to reappear in the blood after $24 \mathrm{~h}$. By $100 \mathrm{~h}, 100 \%$ of crabs were moribund. The septicaemic effects of the isolate were reflected in the low levels of its killing by blood-cell lysate and serum. By contrast, 17 was only slowly removed from circulation and caused the rapid mortality of all crabs in $<3 \mathrm{~h}$. A large decline in the number of circulating blood cells following injection of 17 was mirrored by an accumulation of these cells in the gills. Initial experiments suggest that the death of the crabs following injection with 17 may be caused by toxic extracellular bacterial products that exert their effects on the blood cells and nervous system of the crabs.

Keywords: enzymic activity, histopathology, bacterial extracellular products

\section{INTRODUCTION}

Chitin is an abundant polymer within the marine environment, thus chitinolytic bacteria are both common and vital to nutrient recycling (reviewed by Keyhani \& Roseman, 1999). Chitin breakdown is largely restricted to the moulted shells of marine crustaceans. In situations where chitin degradation occurs on the exoskeletons (cuticle) of living crustaceans the condition is known as shell disease or black-spot. In natural populations the disease is rarely reported in more than $10 \%$ of individuals (e.g. Ayres \& Edwards, 1982; Baross \& Tester, 1978). However, elevated levels of shell

Abbreviations: $D M A B, p$-dimethylaminobenzaldehyde; $E C P$, extracellular product; $\mathrm{pNP}, p$-nitrophenol; SEM, scanning electron microscopy. disease have frequently been reported amongst crustaceans living in degraded environmental conditions, such as aquaculture systems (e.g. Delves-Broughton \& Poupard, 1976; Prince et al., 1995) or polluted environments (e.g. Young \& Pearce, 1975, Sawyer, 1991).

The disease commences with the removal of the nonchitin-containing outer layer of the exoskeleton, called the epicuticle, and may occur by proteolytic and lipolytic microbial activities (Cipriani et al., 1980), predatory or cannibalistic attacks (Dyrynda, 1998), chemical attack (Schlotfeldt, 1972) or the abrasive action of sediment and/or articulated body parts (Young, 1991; Vogan et al., 1999). Once the underlying chitin-containing procuticle is exposed, shell degradation is largely attributed to the chitinolytic members of the lesion microbial community (for reviews see Getchell, 1989; Stewart, 1993). 
Bacteria belonging to the genera Vibrio, Aeromonas, Pseudomonas, Alteromonas, Flavobacterium, Spirillum, Moraxella, Pasteurella and Photobacterium are all reported as probable agents involved in the disease syndrome (Getchell, 1989). Although the disease is not believed to be fatal in its initial stages, mortality is thought to result in the later stages of the disease either from (i) unsuccessful moulting (e.g. Smolowitz et al., 1992) or (ii) as a result of septicaemic infections by pathogenic bacteria originating by entry through the lesion sites (Baross \& Tester, 1978; Vogan et al., 2001).

Previous studies have found high prevalences of shell disease in the commercially fished edible crab, Cancer pagurus, from the Swansea Bay region of South Wales (Vogan et al., 1999). The current study investigates the pathogenic effects of a number of exoskeletal chitinolytic isolates both in terms of their abilities to degrade cuticular chitin (i.e. external pathogenicity) and their effect on the host following penetration into blood (i.e. internal pathogenicity).

\section{METHODS}

Animals. Edible crabs, Cancer pagurus, were obtained from pots anchored between Oxwich Bay and Pwlldu Head, or Langland Bay, Gower, UK. All were intermoult males (100-150 mm carapace width). Initial bacterial isolation was performed immediately after return to the laboratory on crabs with variable levels of shell disease on their external body surfaces. Crabs used in bacterial pathogenicity experiments were maintained in aerated tanks in a circulating sea-water aquarium $\left(15^{\circ} \mathrm{C}\right.$ and $35 \%$ salinity) for about $24 \mathrm{~h}$ prior to their use and had $<1 \%$ of their external surfaces covered with black-spot lesions.

Bacteria. Vibrio alginolyticus (NCIMB 1339), Vibrio splendidus (NCIMB 2251), Vibrio vulnificus (NCIMB 2139) and Vibrio pelagius (Listonella pelagia; NCIMB 1900) were all routinely maintained on tryptic soy agar containing $1 \% \mathrm{NaCl}$ (TSA $+1 \% \mathrm{NaCl}$ ) or Difco Marine Agar 2216 (MA).

Bacterial isolation. Bacteria were cultured from the blood (haemolymph) and exoskeleton of healthy and shell-diseased specimens of C. pagurus. Bacteria from the blood of crabs were isolated on MA as described by Vogan et al. (2001). Exoskeletal bacterial isolates were obtained by abrasion of shell-disease lesion and non-lesion areas of both dorsal and ventral surfaces (see Fig. 1) using a sterile scalpel. Each scraping was transferred into $600 \mu \mathrm{l}$ sterile $3 \cdot 2 \% \mathrm{NaCl}$ solution, homogenized briefly and spread-plated in triplicate onto MA and chitin agar (comprising an underlay containing $20 \mathrm{~g}$ Difco agar l-1, $1 \mathrm{~g} \mathrm{NH}_{4} \mathrm{Cl} \mathrm{l}^{-1}, 75 \mathrm{mg} \mathrm{K}_{2} \mathrm{HPO}_{4} \cdot 3 \mathrm{H}_{2} \mathrm{O} \mathrm{l}^{-1}$, $25 \mathrm{mg} \mathrm{FeSO}_{4} .7 \mathrm{H}_{2} \mathrm{O} l^{-1}, 50 \mathrm{ml} 1 \mathrm{M}$ Tris $/ \mathrm{HCl}, 500 \mathrm{ml}$ sea water and $450 \mathrm{ml} \mathrm{H}_{2} \mathrm{O}, \mathrm{pH} 7 \cdot 5$, plus an overlay containing $10 \mathrm{~g}$ Difco Noble agar, $75 \mathrm{mg} \mathrm{K}_{2} \mathrm{HPO}_{4} \cdot 3 \mathrm{H}_{2} \mathrm{O} \mathrm{l}^{-1}, 25 \mathrm{mg}$ $\mathrm{FeSO}_{4} \cdot 7 \mathrm{H}_{2} \mathrm{O} \mathrm{l}^{-1}, 50 \mathrm{ml} 1 \mathrm{M}$ Tris/ $\mathrm{HCl}, 500 \mathrm{ml}$ colloidal chitin and $450 \mathrm{ml} \mathrm{H}_{2} \mathrm{O}, \mathrm{pH} 7 \cdot 5$ ). Plates were incubated at 10,20 or $25^{\circ} \mathrm{C}$ for up to 10 days. Pure cultures from randomly chosen colonies were placed on MA slopes and stored at $4{ }^{\circ} \mathrm{C}$ until use.

Characterization of chitinolytic bacterial isolates. Based on preliminary characterization (colony morphology, chitinase production on chitin agar, bacterial morphology and Gramstaining), nine chitinolytic isolates were chosen for initial phenotypic profiling. Each of the chosen isolates, designated I1-I9, were distinctive in terms of these tests. Known strains of
V. alginolyticus (NCIMB 1339 and a further strain courtesy of DRIM Laboratories, Montpellier, France) and V. splendidus (courtesy of DRIM Laboratories) were run in parallel. Isolates were taken from slopes and subcultured twice on MA plates before determining each test characteristic.

Temperature tolerance, the level and requirement of sodium ions for growth, susceptibility towards the vibriostatic agent V0129 (10 and $150 \mu \mathrm{g})$, motility and catalase activity were all investigated using standard techniques. API $20 \mathrm{E}$ and $20 \mathrm{NE}$ isolate profiles were obtained according to the instructions of the manufacturer (bioMérieux) with the following recommended modifications for use with marine bacteria. Suspension medium (AUX, supplied with the bioMérieux API 20NE kit) used for assimilation tests in API 20NE was supplemented with $200 \mu \mathrm{l}$ saturated $\mathrm{NaCl}$ solution. All other bacterial suspensions for strip inoculations were made using $3 \cdot 2 \% \mathrm{NaCl}$. Biolog GN Microplates (Don Whitely Scientific) were used to assess utilization of 95 different carbon sources by the isolates. The plating protocol of the supplier for use with marine bacteria was followed using a marine cation supplement $\left(2.5 \% \mathrm{NaCl}, 0.8 \% \mathrm{MgCl}_{2}, 0.05 \% \mathrm{KCl}\right)$ as the suspension medium. All plates were incubated at $25^{\circ} \mathrm{C}$ for $72 \mathrm{~h}$ and positive reaction wells were recorded.

Bacteria were also tested for their ability to produce caseinase, lipase, phospholipase and gelatinase on agar plates as described by Zhang \& Austin (2000). Two selective agars were used for the partial differentiation of Vibrio spp. Cellobiosecolistin agar (CC agar) and Vibrio vulnificus medium (VVM agar) were prepared and isolate-inoculated plates were incubated as described by Høi \& Dalsgaard (2000) and CerdàCuéllar et al. (2000), respectively. Presumptive V. vulnificus isolates produce yellow colonies on CC agar and bright yellow colonies with yellow diffusion haloes on VVM agar. According to Cerdà-Cuéllar et al. (2000), on VVM agar Pseudomonas aeruginosa, Vibrio (Listonella) anguillarum, Vibrio cholerae, Vibrio mediterranei, Vibrio mimicus and Vibrio proteolyticus appear as green colonies, whereas Vibrio campbellii, Vibrio carchariae (harveyi) and Vibrio navarrensis produce yellow colonies.

Extracellular chitinase activity of bacterial isolates. The patterns of chitinase production by bacterial isolates were determined in a minimal chitin medium which consisted of $4 \%(\mathrm{w} / \mathrm{v}$ ) Sigma sea salts, $5 \%$ (v/v) $1 \mathrm{M}$ Tris/HCl, $\mathrm{pH} 7 \cdot 5$, and $1 \%(\mathrm{w} / \mathrm{v}$ ) chitin powder (from crab shells; Sigma). Isolates used in chitinase production experiments were initially grown for $24 \mathrm{~h}$ in tryptic soy broth (TSB) supplemented with $1 \% \mathrm{NaCl}$ and washed twice in sterile Tris-buffered sea-salt solution $(4 \%, \mathrm{w} / \mathrm{v}$, Sigma sea salts, $5 \%$, v/v, $1 \mathrm{M}$ Tris/ $\mathrm{HCl}, \mathrm{pH} 7.5)$ prior to inoculation into the minimal chitinase medium. Bacterial counts were adjusted to give a final concentration of $2 \times 10^{6}$ bacteria ml ${ }^{-1}$ in inoculated minimal medium. Both test and control flasks (containing sterile chitinase medium) were incubated in triplicate at $25^{\circ} \mathrm{C}$ and aliquots were removed aseptically at a number of time points. Initial time series chitinase profiles (using I3; see Table 1) were determined from $50 \mathrm{ml}$ cultures with aliquots $(6 \mathrm{ml})$ taken at 0,48 and $96 \mathrm{~h}$, and thereafter at every $24 \mathrm{~h}$ until the bacteria had been growing for $408 \mathrm{~h}$. All other chitinase incubation experiments were measured in cultures $(25 \mathrm{ml})$ with $4 \mathrm{ml}$ aliquots taken after 0, 192 and $408 \mathrm{~h}$. Each aliquot was enumerated on a Thoma bacterial counting chamber and the remainder was centrifuged $(1800 \mathrm{~g}, 5 \mathrm{~min}$, room temperature) before filter-sterilization. Aliquots of each crude enzyme supernatant were heat-inactivated $\left(100^{\circ} \mathrm{C}, 5 \mathrm{~min}\right)$. All enzyme and heat-inactivated supernatant samples were stored at $-20{ }^{\circ} \mathrm{C}$ until analysis of their chitinolytic abilities. 

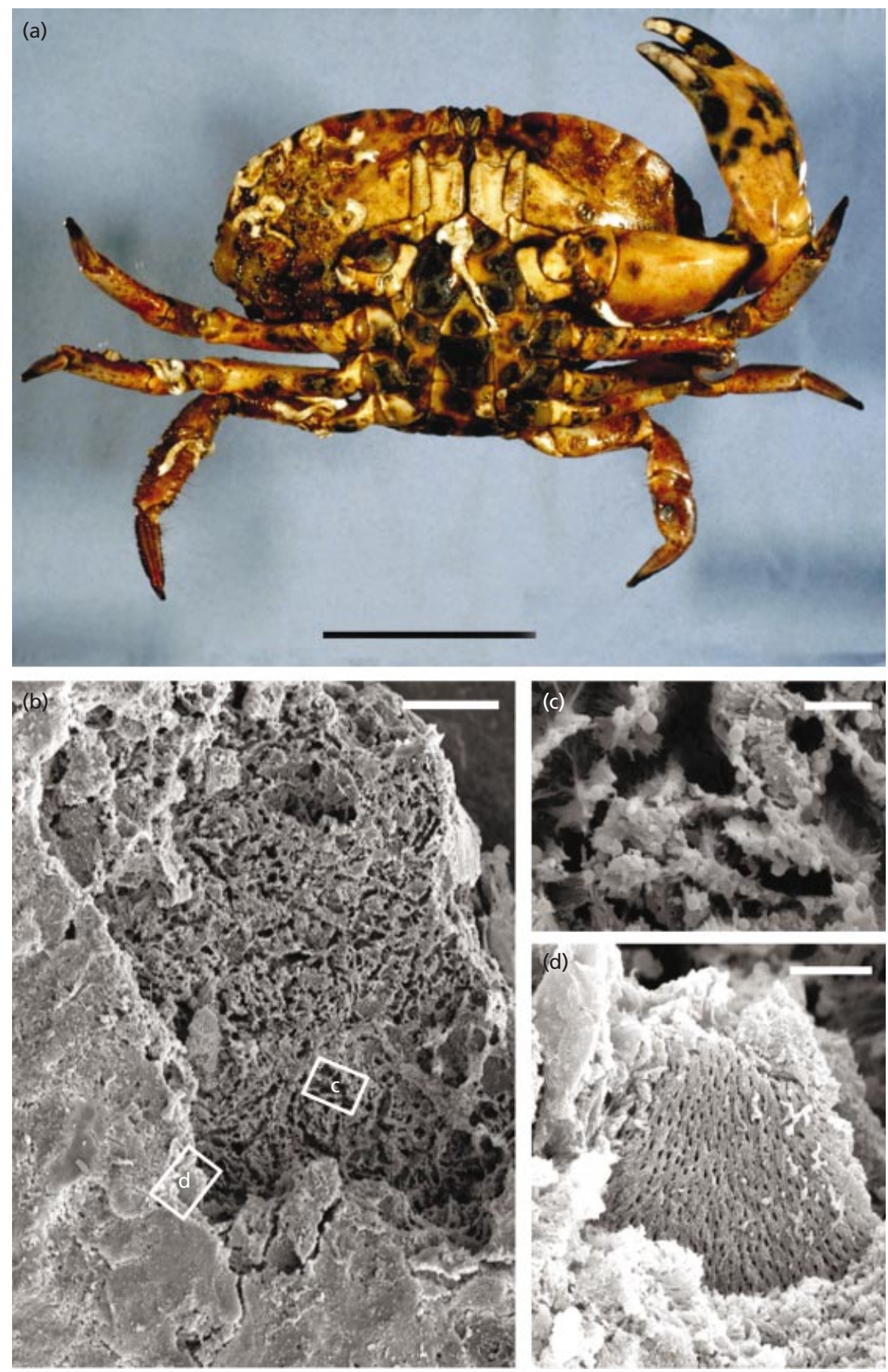

Fig. 1. (a) The ventral surfaces of $C$. pagurus displaying the characteristic black-spot lesions of shell disease. (b) Low power scanning electron micrograph of a ventral carapace lesion. Boxed regions are enlarged in (c) and (d). Note the columnar pattern of degradation in the central regions of the lesion (c) which contrasts with the lamellar cleavage planes at lesion peripheries (d). Bars: $5 \mathrm{~cm},(\mathrm{a}) ; 100 \mu \mathrm{m}(\mathrm{b}) ; 10 \mu \mathrm{m}(\mathrm{c}, \mathrm{d})$.

Total chitinase activity was assessed by the production of $\mathrm{N}$ acetylglucosamine when the crude enzyme supernatants were incubated with colloidal chitin using a method adapted from Yanai et al. (1992). Briefly, enzyme supernatant samples $(250 \mu \mathrm{l})$ were incubated with $125 \mu \mathrm{l}$ colloidal chitin and $125 \mu \mathrm{l}$ $0 \cdot 1 \mathrm{M}$ Tris/ $\mathrm{HCl}, \mathrm{pH} 7 \cdot 5$, containing $0.08 \%$ sodium azide, for $46 \mathrm{~h}$ at $25^{\circ} \mathrm{C}$. After centrifugation $\left(21000 \mathrm{~g}, 2 \mathrm{~min}, 25^{\circ} \mathrm{C}\right)$,
$125 \mu \mathrm{l}$ supernatant was added to $25 \mu \mathrm{l} 0.8 \mathrm{M}$ boric acid (adjusted to $\mathrm{pH} 10 \cdot 2$ using $\mathrm{KOH}$ ) and the mixture was heated in a boiling water bath for $3 \mathrm{~min}$. The sample was cooled (30 min, $4{ }^{\circ} \mathrm{C}$ ) and $750 \mu \mathrm{l} p$-dimethylaminobenzaldehyde (DMAB) solution $[1 \%, \mathrm{w} / \mathrm{v}, p$-dimethylaminobenzaldehyde (Sigma), $99 \%, v / v$, glacial acetic acid, $1 \%, v / v$, concentrated $\mathrm{HCl}]$ was added. After incubation at $37^{\circ} \mathrm{C}$ for $20 \mathrm{~min}$, each sample 
Table 1. Summary of the principal test characteristics for chitinolytic bacterial isolates 1-9 (I1-19)

All isolates were found to be Gram-negative rods which were motile in liquid medium. Cluster groups are based on the isolates displaying $85 \%$ simple matching coefficients to each other (see Fig. 2). +, Positive activity; - , negative enzyme activity; NG, strain did not grow on medium.

\begin{tabular}{|c|c|c|c|c|c|c|c|c|c|}
\hline \multirow[t]{3}{*}{ Test } & \multicolumn{9}{|c|}{ Cluster group } \\
\hline & \multicolumn{4}{|c|}{ A } & \multicolumn{2}{|c|}{$\mathrm{D}$} & \multirow{2}{*}{$\begin{array}{l}\text { E } \\
\text { I5 }\end{array}$} & \multirow{2}{*}{$\begin{array}{l}\text { F } \\
\text { I7 }\end{array}$} & \multirow{2}{*}{$\begin{array}{l}\text { G } \\
\text { I9 }\end{array}$} \\
\hline & I1 & I2 & I6 & I3 & I4 & I8 & & & \\
\hline $\mathrm{Na}^{+}$requirement & + & + & + & + & - & - & + & + & + \\
\hline Max. $\mathrm{Na}^{+}$where growth observed (\%) & 8 & 8 & 8 & 10 & 3 & 3 & 3 & 3 & 10 \\
\hline Oxidase & + & + & + & + & - & - & + & + & + \\
\hline Catalase & + & + & + & + & + & + & + & - & + \\
\hline V0129 sensitivity & + & + & + & + & - & - & + & + & - \\
\hline Water-soluble pigment & - & - & - & - & - & + (black) & - & - & - \\
\hline D-Mannitol utilization & + & + & + & + & - & - & + & + & + \\
\hline Caseinase & - & + & - & - & + & + & - & + & - \\
\hline Gelatinase ${ }^{*}$ & $-(+)$ & $\mathrm{NG}(+)$ & $-(+)$ & $\mathrm{NG}(+)$ & + & + & $\mathrm{NG}(-)$ & $\mathrm{NG}(+)$ & - \\
\hline Phospholipase & + & + & + & + & + & + & - & - & NG \\
\hline Lipase & - & - & - & - & + & + & + & + & NG \\
\hline Colony colour on VVM agar & NG & NG & NG & Green/yellow & NG & NG & NG & NG & NG \\
\hline Colony colour on CC agar & \multicolumn{4}{|c|}{ Green/yellow } & Green & Yellow & Yellow & NG & NG \\
\hline \multirow[t]{2}{*}{ Closest genus $\dagger\left(\% S_{\mathrm{SM}}\right)$} & \multicolumn{4}{|c|}{ Vibrio } & \multicolumn{3}{|c|}{ Xanthomonas } & Vibrio & \\
\hline & $(100)$ & $(100)$ & $(100)$ & (100) & $(80)$ & $(90)$ & (88) & $(82)$ & (82) \\
\hline \multirow[t]{2}{*}{ Closest species† $\left(\% S_{\mathrm{SM}}\right)$} & & V. splendidus & & V. anguillarum & \multicolumn{2}{|c|}{ X. maltophilia } & V. splendidus & V.pelagius & V. splendidus \\
\hline & (93) & (87) & (93) & (82) & (86) & (86) & (80) & (71) & (80) \\
\hline
\end{tabular}

*Values in parentheses indicate differing results detected using API commercial test kits.

† Compared to those defined in Holt et al. (1994).

was plated in triplicate onto a 96-well microtitre plate and the $\mathrm{OD}_{550}$ was measured. Sample blanks (containing $250 \mu \mathrm{l}$ heatinactivated supernatants) and negative controls (consisting of $250 \mu$ supernatant from sterile control culture flasks) were run in parallel. A standard curve, for the linear range of the assay, was produced using serial dilutions of $\mathrm{N}$-acetylglucosamine (Sigma) and DMAB detection. One unit of enzyme activity was defined as the amount of enzyme required to produce sugars equivalent to $1 \mu \mathrm{mol} N$-acetylglucosamine $\min ^{-1}$ under the above conditions.

'Endo-acting' chitinase activity (i.e. that principally acting on the central portions of the chitin polymer) of each supernatant was detected in a turbidometric microplate assay using colloidal chitin (adapted from Tronsmo \& Harman, 1993). Aliquots $(150 \mu \mathrm{l})$ of crude enzyme supernatants (test samples) and heat-inactivated supernatants (sample blanks) were added in triplicate to wells that contained $50 \mu \mathrm{l}$ colloidal chitin. Negative controls that contained $150 \mu$ of supernatants from sterile control culture flasks were also included on each plate. After a $10 \mathrm{~s}$ shake, a time zero $\mathrm{OD}_{492}$ reading was taken on a microplate reader. The plates were sealed and incubated at $25^{\circ} \mathrm{C}$ for 14 days. Endochitinase activity for each bacterial supernatant was defined as a reduction in the sample $\mathrm{OD}_{492}$ between time zero and 14 days compared with its sample blank.

The chitinolytic activities of ' exo-acting' chitinases (acting on terminal locations on the chitin polymer) were quantified in two separate assays by the release of $p$-nitrophenol (pNP) from $p$-nitrophenyl- $N$-acetyl- $\beta$-D-glucosaminide and $p$-nitrophenyl- $\beta$-D-N, $N^{\prime}$-diacetylchitobiose (Sigma), respectively. Stock solutions of each substrate were prepared at a concentration of $0.275 \mathrm{mM}$ in $1 \mathrm{M}$ Tris $/ \mathrm{HCl}(0.02 \%$ sodium azide) and frozen at $-20{ }^{\circ} \mathrm{C}$ until use in the microtitre assay. Crude enzyme supernatant $(10 \mu \mathrm{l})$ was added in triplicate to wells containing $90 \mu \mathrm{l}$ pNP substrate stock solutions. Sample blanks (10 $\mu$ l heat-inactivated supernatants) and negative controls (sterile control culture supernatants) were run in parallel. The pNP substrate microplates were sealed and incubated at $25^{\circ} \mathrm{C}$ for $46 \mathrm{~h}$. Reactions were terminated by the addition of $10 \mu \mathrm{l} 1 \mathrm{M} \mathrm{NaOH}$ to each well and the $\mathrm{OD}_{405}$ was measured. One unit of enzyme activity was defined as the amount of enzyme activity that liberated $1 \mu \mathrm{mol} \mathrm{pNP} \mathrm{min}^{-1}$ under the above conditions. According to dal Soglio et al. (1998), $1 \mathrm{mM}$ pNP is equivalent to an $\mathrm{OD}_{405}$ increase of 6.367 .

Clearance of chitinolytic isolates in crabs. I4 and I7 (see Table 1) were grown overnight in $\mathrm{TSB}+1 \% \mathrm{NaCl}$ at $25^{\circ} \mathrm{C}$ with shaking. The bacteria were washed twice in sterile marine saline $\left[\mathrm{MS} ; 0.58 \mathrm{M} \mathrm{NaCl}, 20 \mathrm{mM} \mathrm{CaCl}_{2}, 12 \mathrm{mM} \mathrm{KCl}\right.$, $0.56 \mathrm{mM}$ disodium phosphate, 0.05 M Tris(hydroxymethyl)methylamine, $\mathrm{pH} 7 \cdot 4]$ and adjusted to $2 \times 10^{9}$ bacteria $\mathrm{ml}^{-1}$. All injections into crabs were made through the surfacesterilized soft membrane where the fifth pereiopod (fourth walking limb) joins the body. Blood samples were removed for blood-cell (haemocyte) and bacterial counts from the soft membrane on the cheliped (fighting limb) as described in Vogan et al. (2001).

Total blood volume in groups of C. pagurus was estimated using the Amaranth dye dilution technique (Smith \& Ratcliffe, $1980)$ and the volume of bacterial suspension $\left(2 \times 10^{9}\right.$ bacteria $\mathrm{ml}^{-1}$ ) to be injected was calculated so as to give a circulating blood dose of $2 \times 10^{6}$ bacteria $(\mathrm{ml} \text { blood })^{-1}$. Prior to bacterial injection into the crabs, a blood sample was removed from each animal for blood-cell counts and bacterial sterility checks. Control crabs received a dose of sterile MS in place of the bacterial suspension. After 1, 6, 24 and 48 h, a $200 \mu \mathrm{l}$ blood sample was removed from each crab and serially diluted in sterile sea salts solution (Sigma). A $100 \mu \mathrm{l}$ aliquot was spread in triplicate onto TSA $+1 \% \mathrm{NaCl}$ plates and incubated for about $24 \mathrm{~h}$ to allow for bacterial growth. The original bacterial suspension $\left(2 \times 10^{9} \mathrm{cell} \mathrm{ml}^{-1}\right)$ was also plated. Total blood-cell 
counts were conducted between 5 min and 48 h post-injection using a haemocytometer.

Experiments involving injection of extracellular products (ECPs) from I7 (see Table 1) followed the same protocol, except for the substitution of filter-sterilized $(0 \cdot 22 \mu \mathrm{m})$ aliquots from $48 \mathrm{~h} \mathrm{TSB}+1 \% \mathrm{NaCl}$ cultures in test animals and filtersterilized un-inoculated TSB $+1 \% \mathrm{NaCl}$ for control animals.

Crabs were considered dead when no ventilatory or sensory movements were detected. Crabs that died during the experimental period were immediately fixed for histology. Control crabs were sacrificed for histology at the end of the experimental period $(48 \mathrm{~h})$.

Histopathology and scanning electron microscopy (SEM). All crabs that died during the experimental period were immediately injected with about $50 \mathrm{ml}$ Bouin's sea water fixative and dissected to remove the main organs. Tissues were stored and processed as detailed in Vogan et al. (2001). Wax sections (about $10 \mu \mathrm{m}$ thick) were cut and stained using Cole's haematoxylin and eosin. Photographs were taken using a Zeiss Photomicroscope II. For SEM, small pieces (about $2 \mathrm{~mm}^{2}$ ) of lesion and non-lesion crab cuticle were fixed for about $12 \mathrm{~h}$ in ethanol and transferred into acetone $(30 \mathrm{~min}$ ) prior to air-drying and coating with gold. All samples were examined with a JEOL scanning electron microscope.

Antibacterial activity assay. The in vitro antibacterial activity of crab blood towards I4 and I7 was assessed using a method described by Chisholm \& Smith (1992) adapted for use in a turbidometric growth microplate assay. Test samples containing $225 \mu \mathrm{l}$ of either clotted whole blood (serum; $6.4 \times$ $10^{4} \pm 0.8 \times 10^{4} \mu$ g protein $\mathrm{ml}^{-1}$; SEM $\pm 1, n=6$ ) or a lysate of the blood cells $\left(1 \cdot 0 \times 10^{2} \pm 0 \cdot 2 \times 10^{2} \mu \mathrm{g}\right.$ protein $\mathrm{ml}^{-1} ; \operatorname{SEM} \pm 1$, $n=6$ ), prepared as described by Vogan \& Rowley (2002), were incubated with $25 \mu \mathrm{l} \mathrm{I} 4$ or I7 in MS $\left(4 \times 10^{6}\right.$ bacteria $\left.\mathrm{ml}^{-1}\right)$. For controls, test samples were substituted with equal volumes $(225 \mu \mathrm{l})$ of sterile MS. Sample blanks contained $225 \mu \mathrm{l}$ of each particular test sample and $25 \mu \mathrm{l}$ sterile MS. All samples, for a given bacterial isolate, were incubated at room temperature with constant shaking for $30 \mathrm{~min}$. They were then rapidly flooded with $2 \cdot 25 \mathrm{ml} \mathrm{TSB}+1 \% \mathrm{NaCl}$ and $200 \mu \mathrm{l}$ aliquots were plated in triplicate into a 96 -well microtitre plate. The $\mathrm{OD}_{550}$ of each plate was measured on a microplate reader, after incubation at $25{ }^{\circ} \mathrm{C}$ for differing lengths of time so as to give an $\mathrm{OD}_{550}$ of control wells that lies in the middle of the exponential growth phase for each bacterial isolate.

Protein concentrations in serum and blood-cell lysate were determined using a BCA (bicinchoninic acid) assay kit in accordance with the manufacturer's instructions for use in a microtitre plate (Pierce \& Warriner). All samples were replicated in triplicate and calibrated against a bovine serum albumin (BSA) standard curve $\left(100-1000 \mu \mathrm{g} \mathrm{ml}^{-1}\right.$ ) run on the same plate.

Data analyses. All data used for numerical taxonomic comparisons were converted into binary figures, scoring ' 1 ' for positive reactions and ' 0 ' for negative reactions. Inconclusive results were omitted from all comparisons. A positive test result (1) was recorded when $75 \%$ of the strains tested were positive, a negative test result $(0)$ was recorded when $25 \%$ of the strains tested were positive and tests with results between 25 and $75 \%$ were taken as being inconclusive (omitted from comparison), as described by Holt et al. (1994). The isolate test results were then compared to each other and to data published in Holt et al. (1994) using the simple matching coefficient of similarity. The resultant similarities $(0-100 \%)$ were then plotted onto dendrograms using the
UPGMA (unweighted pair group method using arithmetic averages) clustering method in the Genstat software package.

Bacterial diversity frequencies were assessed using contingency tables followed by either $\chi^{2}$ test (for tables with $<$ two rows or columns) or Fisher's exact test (for tables with $\leqslant$ two rows or columns). For mean values \pm SE the appropriate parametric test ( $t$-test or ANOVA) was employed. For ANOVA, the Tukey's, Bonferroni and Dunnett post-tests were used as recommended by Instat (GraphPad).

\section{RESULTS AND DISCUSSION}

\section{Bacterial diversity in shell disease lesions and diseased crabs}

Crabs with shell disease syndrome show characteristic darkened lesions through the cuticle (Fig. 1a). Such lesions have previously been shown to occur on all regions of the exoskeleton (Vogan et al., 1999). SEM examination of these lesions revealed the extensive nature of the cuticular erosion into the chitinous procuticle (Fig. $1 \mathrm{~b}-\mathrm{d}$ ). In all regions of the lesion the epicuticle was absent as indicated by the appearance of small pore canals (about $1 \mu \mathrm{m}$ in diameter) that permeate through the underlying procuticle. Exoskeletal degradation was most severe towards the centre of the lesion, which tended to display sever pitting with a columnar pattern of degradation (Fig. 1c). Towards the peripheries of the lesion the degree of pitting decreased and displayed areas of exposed procuticle which had broken along the lamellar cleavage planes that run parallel to the epidermis (Fig. 1d).

The majority of bacteria cultured from the blood $(n=$ $19)$ and exoskeleton $(n=67)$ of shell-diseased C. pagurus were Gram-negative rods $(57.9$ and $89.6 \%$ respectively). The proportion of Gram-positive eubacteria was significantly higher amongst the blood-derived isolates $(33 \%)$ than those found in the exoskeleton $\left(7.7 \% ; \chi^{2}\right.$ test, $\left.P=0.0009\right)$. Chitinase-producing bacteria were isolated from the blood $(21 \cdot 1 \%$ of total culturable isolates) and from both lesioned and nonlesioned portions of the exoskeleton $(26.9 \%$ of total culturable isolates). No significant differences were found in the percentages of culturable chitinolytic bacteria residing in lesion $(31 \%)$ and non-lesion $(15 \%)$ areas (Fisher's exact test, $P=0 \cdot 2289$ ).

From the 22 bacterial colony types that were positive for chitinolytic activity, 9 isolates (designated I1-I9) were selected for further phenotypic analysis. Selection was based on their distinct behaviour in several preliminary tests, including Gram staining, colony and bacterial morphology. I1 and I8 were from blood of shell-diseased individuals. I2, I4, I5, I6, I7 and I9 were from exoskeletal lesions, while I3 was from a non-lesion area. All were motile, Gram-negative rods that generally varied in length between 0.6 and $2 \mu \mathrm{m}$. However, the rods of I4 were elongate $(1.5-5 \mu \mathrm{m})$ and formed long filamentous chains, whereas those of 19 were almost spherical in appearance. These isolates were clustered based on 157 


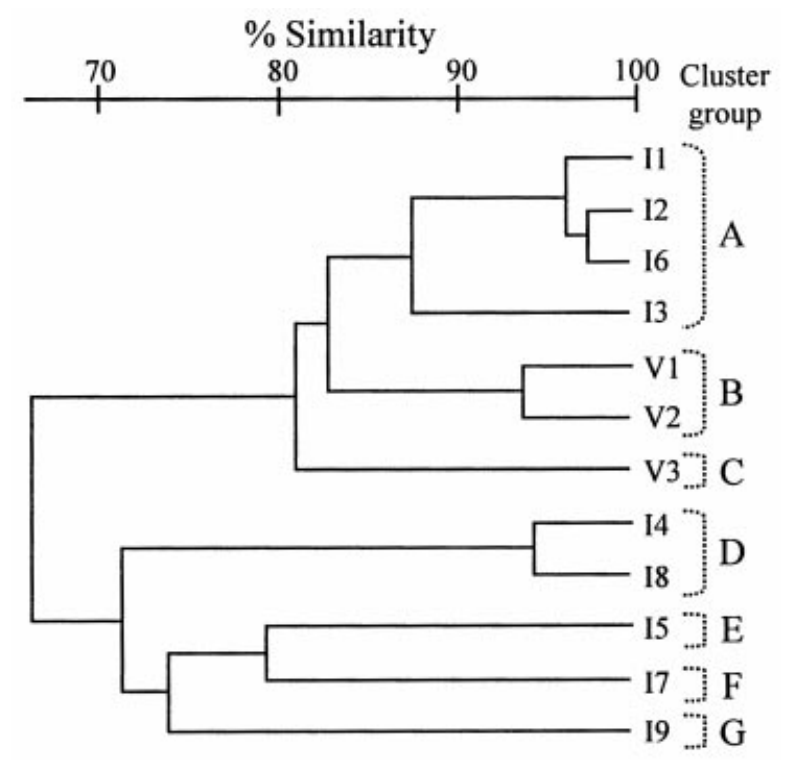

Fig. 2. UPGMA clustering of bacterial isolates based on 157 individual test results, using a simple matching coefficient of similarity. 11-19 are the chitinolytic isolates. V1-V3 are $V$. alginolyticus (NCIMB 1339), V. alginolyticus ('French' strain) and $V$. splendidus, respectively. Cluster groups $A-G$ are based on isolates displaying $85 \%$ simple matching coefficients.

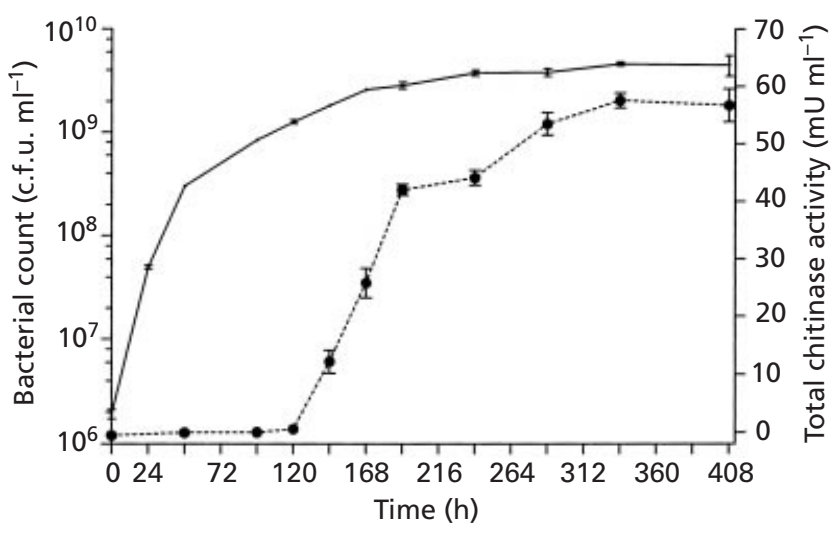

Fig. 3. Total extracellular chitinase activity (---) in relation to growth of cultures (-) of 13 . The bacterial isolate was grown in a minimal chitin powder medium at $25^{\circ} \mathrm{C}$ with shaking for $>408 \mathrm{~h}$. Mean values $\pm 1 \mathrm{SE}$ are shown $(n=3)$.

test characteristics (Fig. 2; Table 1). Bacteria in cluster group A (I1, I2, I3 and I6) differed mainly in their ability to produce $\beta$-galactosidase, ferment amygdalin and arabinose, and in several carbon utilization tests. Cluster D contained two isolates, I4 and I8, that were distinct from all others tested and were less likely to belong within the genus Vibrio. Within the cluster the two strains differed in pigment production, cell form and a small number of carbon utilization tests (Tween 40, $\mathrm{N}$-acetyl-D-glucosamine, acetic acid, cis-aconitic acid, formic acid, glucose-1-phosphate). I5, I7 and I9 were $<85 \%$ similar to all others and hence were contained within individual clusters.

According to Holt et al. (1994) members of the family Vibrionaceae (Bergey's Group 5.2) are Gram-negative, oxidase-positive, motile rods, capable of growth at $37^{\circ} \mathrm{C}$ as long as there is a source of sodium ions. Although growth at $37^{\circ} \mathrm{C}$ was not tested, I1, I2, I5, I6, I7 and 19 all grew at $35^{\circ} \mathrm{C}$ and satisfy the other requirements for classification into Vibrionaceae (Table 1). Comparisons of the test isolates to genera known to contain chitinolytic strains were made using data in Holt et al. (1994) (Table 1). It was found that I1, I2, I3 and I6 were most likely to be Vibrio species (100\% simple matching similarity). I5, I7 and I9 were also most likely to belong within the genus Vibrio (88, 82 and $82 \%$ simple matching similarities, respectively). Like the majority of members of this genus, I5 and I7 were sensitive to the vibriostatic agent V0129 $(150 \mu \mathrm{g})$ and utilized D-mannitol as carbon source. I9, however, was resistant to V0129 and did not utilize D-mannitol, suggesting that it may not be a Vibrio species. However, Holt et al. (1994) recorded that some strains of $V$. alginolyticus, Vibrio cincinnatiensis and Vibrio parahaemolyticus are resistant to V0129. In the current study, a lack of sensitivity to V0129 was also displayed by both $V$. alginolyticus and V. splendidus.

Urakawa et al. (1999) found that V. splendidus strains were the most abundant culturable vibrios from sea water. The current study found five of the nine strains isolated from C. pagurus to be most closely related to $V$. splendidus (2 biovars listed in Holt et al., 1994). I7 displayed joint highest similarities to $V$. pelagius $(71 \%)$ and V.vulnificus. It was concluded that this isolate was unlikely to be a strain of $V$. vulnificus, since it did not produce the characteristic yellow diffusion haloes on VVM agar (Table 1).

The isolates of cluster group D (I4 and I8) were distinct from the other isolates in that they were oxidasenegative and capable of growth in the absence of sodium ions. Chitinolytic Gram-negative rods that are oxidasenegative either belong to the family Enterobacteriaceae (Bergey's Group 5.1) or within Bergey's Group 4.4A (Holt et al., 1994). Although the similarity comparison calculations were based only upon seven test characteristics, I4 and I8 both seem to be most closely related to Xanthomonas maltophilia (as listed in Holt et al., 1994). These results are in agreement with those found when comparing data to the API published profile (data not shown) and the genus identification (Table 1).

It is generally accepted that a large proportion of bacteria in the marine environment are not detected by culturing onto high nutrient media. Over the last 15 years, the existence and nature of a viable but nonculturable state has been much debated (e.g. McDougald et al., 1998). Roszak \& Colwell (1987) described the dynamic state of the microbial cell in its natural state as being able to readily adapt and survive fluctuations in environmental parameters such as nutrient source and 

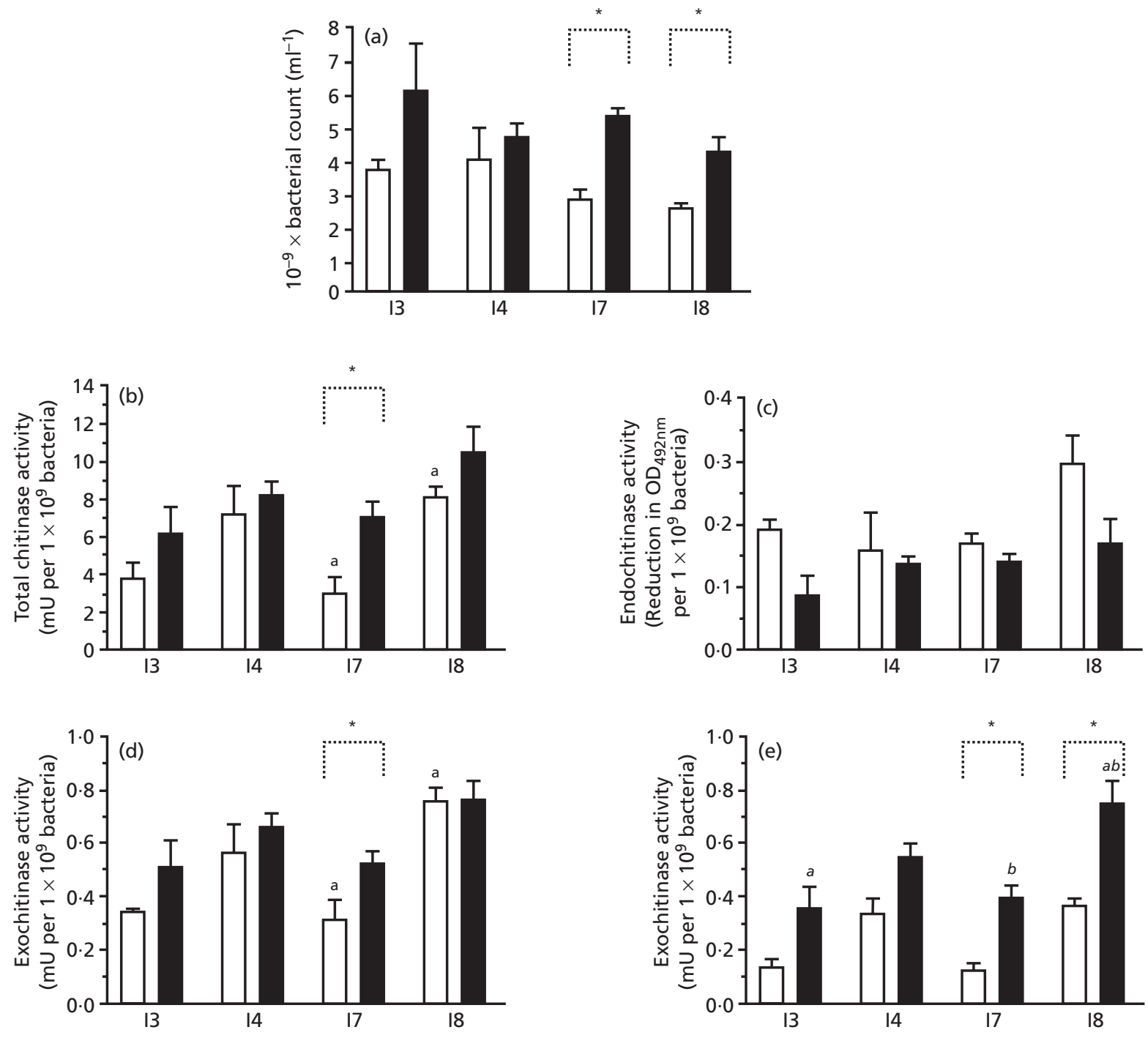

Fig. 4. Chitinase activity from culture supernatants of $13,14,17$ and 18 grown in a minimal chitin powder medium when sampled after $192(\square)$ and $408 \mathrm{~h}$ ( $\square$ ) of growth. (a) Number of bacteria (ml culture) $)^{-1}$. (b) Total chitinase activity, (c) endo-acting chitinase activity and (d, e) exo-acting chitinase against the pNP-monomer (d) and dimer (e) in culture supernatants standardized for $1 \times 10^{9}$ bacteria. Mean values $\pm 1 \mathrm{SE}$ are shown $(n=3)$. Significant differences (paired $t$-test, $P<0.05)$ for individual isolates between 192 and $408 \mathrm{~h}$ are indicated by asterisks. Significant interisolate differences (ANOVA, $P<0.05$; Tukey's post-test, $P<0.05$ ) at either 192 or $408 \mathrm{~h}$ are indicated by roman or italicized letters, respectively.

availability, temperature and light. Thus, culturing onto standard laboratory media provides non-comparable conditions to those of oligotrophy that are found in the natural environment. Hence, only those organisms that are most able to adapt to the specific culture conditions will be able to grow and divide. The current study was not intended to provide an exhaustive list of all microorganisms involved in or capable of exoskeletal degradation. Compared to the vast majority of the marine environment, shell disease lesions provide a high nutrient niche and thus, culturing onto a chitin-containing medium may not be as extreme as, for instance, culturing directly from sediments. Thus, the types of chitinolytic micro-organisms cultured on chitin agar plates might, perhaps, be considered analogous to the primary lesion colonizers, i.e. having the ability to rapidly detect and adapt to newly exposed chitin.

\section{Pathogenicity of chitinolytic isolates}

In this study, the pathogenicity of the chitinolytic (shell disease) isolates was considered on two levels: (i) their ability to contribute to exoskeletal breakdown by the expression of chitinase activity (external pathogenicity), and (ii) should they penetrate the cuticle, their ability to cause damage to host tissues and to overwhelm the cellular and humoral defences of the host (internal pathogenicity). 

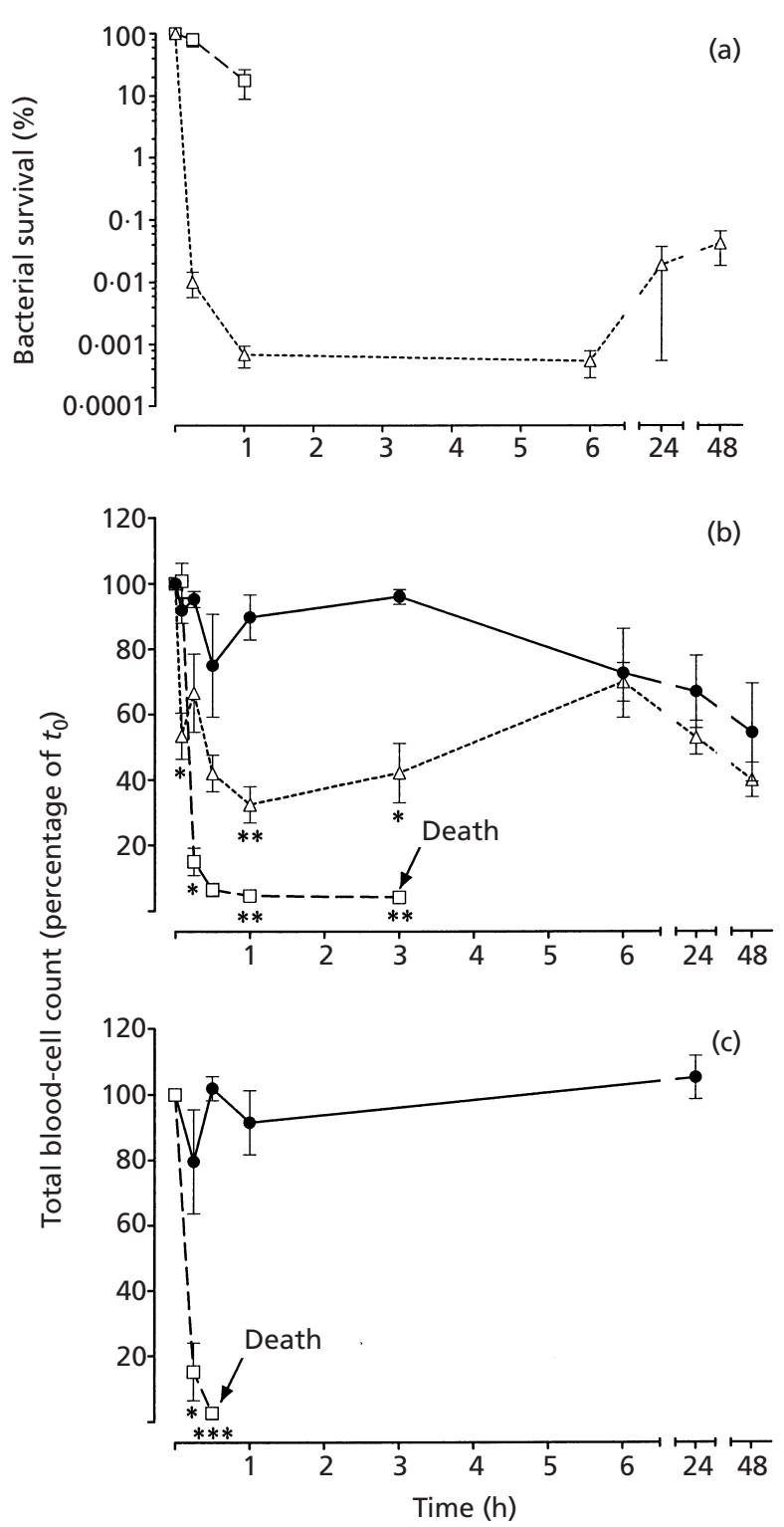

Fig. 5. Response of $C$. pagurus to injection with 14,17 and ECPs from 17. (a) Recovery of viable bacteria from blood samples taken over a $48 \mathrm{~h}$ post-bacterial injection period. (b) Total blood-cell counts from crabs after injection with bacteria (ANOVA, $P<0.05$; Dunnett's post-test, $* P<0.05, * * P<0.01$, compared to the control for the individual time periods). (c) Total blood-cell counts from crabs after injection with $0.5 \mathrm{ml}$ ECPs (unpaired $t$-test, ${ }^{*} P<0.05, * * * P<0.001$ ). Mean values \pm 1 SE are shown $(n=4-6) . \triangle, 14 ; \square, 17 ; \bullet$, control.

\section{Chitinase activity of bacterial isolates (external pathogenicity)}

Preliminary experiments investigating the media required to induce chitinase production in liquid culture found chitinase activity to be present only within inoculated flasks that contained Tris-buffered sea salts and $1 \%$ chitin powder (data not shown). Inoculated flasks, run in parallel, that contained either Tris-buffered sea salts, $1 \%$ chitin powder plus $0.01 \%$ tryptone or
Tris-buffered sea salts alone, did not induce chitinase production (data not shown). The crude chitinase found in supernatant samples was stable at $-20^{\circ} \mathrm{C}$ without a significant loss in activity for at least 6 months (data not shown).

For I3, chitinase activity in the culture supernatant was not detected before $96 \mathrm{~h}$ of bacterial growth (Fig. 3). Activity levels were not significantly higher than control flasks until the isolate had undergone $144 \mathrm{~h}$ of growth (ANOVA, $P<0.01$; Bonferroni post-test, $P<0.001$ from 144 to $408 \mathrm{~h}$ ). The maximal rate of chitinase synthesis was found to occur during the late exponential and early stationary phases of growth (120-192 h). This result is consistent with patterns of chitinase production for Bacillus spp. (Priest, 1977; Frandberg \& Schnurer, 1994) and the fungus Metarhizium anisopliae (Kang et al., 1999). The highest rates of chitinase production between 120 and $192 \mathrm{~h}$ were found when the culture supernatant from I3 was tested for endo- and exo-acting activity (data not shown).

All the isolates tested (I3, I4, I7, I8) were able to grow using $1 \%$ chitin powder as their nutrient source (Fig. 4a). I3 and I4 were found to have similar numbers of bacteria at both 192 and $408 \mathrm{~h}$ (paired $t$-tests for individual isolates, $P>0.05$ ), indicating that these cultures had reached, or were close to reaching the stationary phase of growth (Fig. 4a). This was further reflected when total chitinase activity was standardized for $1 \times 10^{9}$ bacteria with no significant differences found in the amount of extracellular chitinase activity for I3 and I4 between the two sample times (Fig. 4b). When chitinase activity was divided in terms of its activity towards the chitin polymer (i.e. endo- and exo-acting) it was found that I3 and I4 displayed low to moderate levels of both endo- and exo-activity that did not change significantly over the culture period (Fig. 4c-e; paired $t$-tests, $P>0 \cdot 05)$.

In contrast to I 3 and I4, the culture flasks for I7 and I8 were found to have significantly higher bacterial numbers at $408 \mathrm{~h}$ compared to $192 \mathrm{~h}$, suggesting that both cultures were still in exponential growth phase. Significant increases in total chitinase activity between the two incubation times were only found for I7 (Fig. 4b; paired $t$-test, $P=0.0316$ ). Thus, although cultures of I8 were still actively dividing, a higher rate of chitinase synthesis was reached earlier in the growth period. Indeed, I8 cultures showed the highest total chitinase activity per standard number of bacteria at both time periods. I8 produced the highest quantities of endo-acting chitinase at $192 \mathrm{~h}$ and the highest amount of exo-type activity by 408 h (Fig. 4d, e).

Overall within the culture system, I3 and I4, with their faster growth rates and production of moderate levels of enzymes capable of degrading all areas of the chitin polymer, are presumed to represent primary colonizers of chitin powder. By comparison, I7 and I8 grew more slowly, producing greater amounts of chitinases later in the culture period and thus may be more likely to represent secondary colonizers. However, it should be 

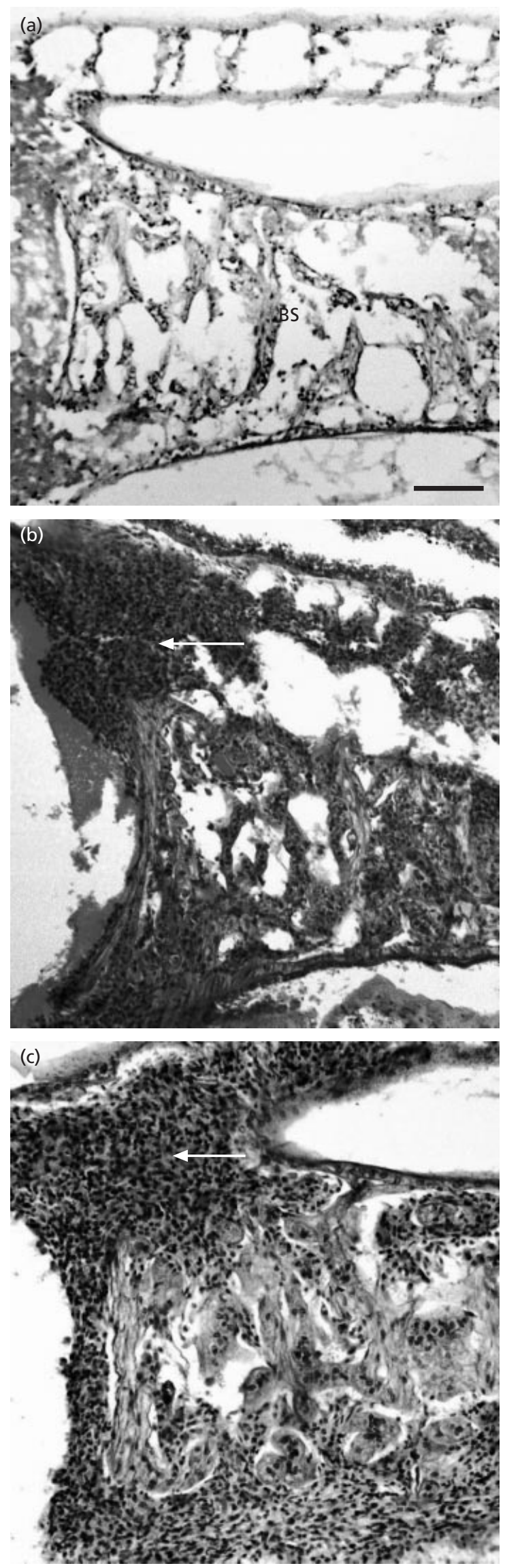

noted that I8 initially ( $192 \mathrm{~h})$ produced high levels of endo-acting enzyme and subsequently $(408 \mathrm{~h}$ ) released large quantities of extracellular enzymes capable of degrading the smaller chitin oligomer. Thus, I8 is potentially best adapted for the degradation of the chitin powder.

The present investigation examined the production of chitinases in bacteria in culture systems and thus is unlikely to reflect their behaviour within the natural lesion community. Pure cultures fail to consider such factors as the interactive effects of the various lesiondwelling bacteria and predation rates (Wardell, 1988). Chitin powder used as a substrate is both deproteinized and decalcified compared to its native form within the cuticle. Both microbial attachment (Dietrich et al., 1984) and chitinase production (Hood \& Meyers, 1977) have been shown to be enhanced when microbial populations are exposed to native chitin. In the current study, preliminary experiments using shell pieces derived from C. pagurus as the growth substrate within the culture system have indicated that levels of extracellular chitinase activity increase for I3 (data not shown). This may be an approach for future studies.

C. pagurus has been shown to have a chitin:protein ratio (calculated from the percentage organic fraction; dry wt) of approximately $7: 1$ within the exoskeleton (Brimacombe \& Webber, 1964). The outermost waterproof cuticle layer, the epicuticle, is ultrathin and composed of lipid and protein alone. Thus, although chitinolytic activity is fundamental to lesion progression, microbial proteases and lipases may also be involved in exoskeletal breakdown, particularly in the initial stages of shell disease (Cipriani et al., 1980). Although not widely investigated, protease activity [specifically gelatinase (collagenase)] was found in all but one of the isolates (I9) while lipase activity amongst the exoskeletal isolates was restricted to cluster groups $\mathrm{D}, \mathrm{E}$ and $\mathrm{F}$ (I4, I5, I7, I8) (Table 1).

\section{Internal pathogenicity}

The internal effects of only two of the isolates (I4 and I7) on the crab host were studied. These were chosen because both isolates displayed distinct morphological characteristics that would enable their identity to be rapidly ascertained on reisolation and growth following intrahaemocoelic injections (i.e. I4 had an elongate cell morphology while I7 was negative for catalase).

I4 was rapidly cleared from the blood of crabs, with $99 \%$ of c.f.u. removed by $15 \mathrm{~min}$ post-injection (Fig. $5 a)$. This rapid reduction in bacterial number coincided

Fig. 6. Changes observed within $C$. pagurus gills after injection with (a) marine saline (control), (b) $2 \times 10^{6} 17 \mathrm{ml}^{-1}$ and (c) ECPs $(0.5 \mathrm{ml})$ from 17 cultures after $48 \mathrm{~h}$ of growth. Arrows indicate the accumulation of blood cells at the base of the gills near the branchial space (BS). Bar, $200 \mu \mathrm{m}$. 
with a marked reduction in the number of circulating blood cells (haemocytes; Fig. 5b). By 24 h, c.f.u. numbers on spread plates increased and at $100 \mathrm{~h}$ mortality was seen in $80 \%$ of individuals. All control (saline-injected) crabs survived and only showed transient changes in the total numbers of circulating blood cells (Fig. 5b).

The dynamics of clearance and pathology of $\mathrm{I} 7$ was markedly different than for I4. Injection of I7 $\left(9 \times 10^{3} \pm\right.$ $6.7 \times 10^{3}$ c.f.u. $\mathrm{ml}^{-1}$ ) resulted in a more modest reduction in the number of viable bacteria from circulation. For example, after $60 \mathrm{~min}$ bacterial numbers had only decreased to $17 \cdot 8 \%$ of the original. The number of circulating blood cells showed a rapid decline, such that after 60 min only $4 \cdot 7 \pm 1 \cdot 1 \%$ (mean value $\pm 1 \mathrm{sE}, n=5$ ) of the cells remained in circulation. Of importance was the finding that by $3 \mathrm{~h}$ post-injection all crabs were moribund. Indeed, after only $15 \mathrm{~min}$ post-injection, crabs showed early changes in their behaviour, including retraction of eye stalks and reduced or increased gill ventilation movements. Subsequently, they all exhibited loss of limb movement by $60 \mathrm{~min}$ and some also showed tremors in their walking limbs. Because such changes indicated that mortality may have been caused by toxins (i.e. ECPs), crabs were injected with filtersterilized culture filtrates taken from $48 \mathrm{~h}$ cultures of $\mathrm{I} 7$. All crabs injected were moribund $60 \mathrm{~min}$ after injection, while culture filtrate from un-inoculated cultures had no effect. The decline in the number of circulating blood cells seen after injection of $I 7$ was also observed with the crude ECP preparation (Fig. 5c). Furthermore, the behaviour of crabs injected with ECPs was the same as that seen following injection of I7 bacteria. Histological examination of crabs injected with I7 bacteria or ECPs revealed a massive accumulation of blood cells in the gills (Fig. 6). Such accumulations effectively blocked the central vascular region of the gills (branchial spaces). There was also evidence in other organs that blood cells dropped out of circulation and attached to such surfaces following exposure to ECPs.

Much is known of the cellular defence responses in crustaceans to micro-organisms. Injection of heatkilled Bacillus cereus into shore crabs (Carcinus maenas) results in their rapid clearance as a result of the formation of clumps of blood cells and bacteria, termed nodules, in the gills (Smith \& Ratcliffe, 1981). These observations largely accounted for the rapid reduction in the number of circulating blood cells and bacteria. In the current study with I4, following an initial rapid clearance of the bacteria, presumably by nodule formation, there was some evidence that bacterial replication occurred in vivo, leading to limited septicaemia and death. It must be remembered, however, that the dose injected $\left(2 \times 10^{6}\right.$ bacteria $\mathrm{ml}^{-1}$; Thoma count $)$ and the method of delivery suggest that this bacterium has limited virulence in edible crabs.

The mechanism by which I7 kills the crabs is clearly different to that employed by I4. In particular, injection of culture filtrates (containing ECPs) resulted in the same symptoms observed after the injection of washed I7 bacteria. Hence, in the case of I7, ECPs appear to be major determinants of pathogenicity. There is surprisingly little known about the mechanisms of pathogenicity for vibrios in marine invertebrates. A number of heat-sensitive proteases produced by V. parahaemolyticus have been shown to be toxic for tiger prawns (Penaeus monodon), but the nature of these enzymes is unknown (Sudheesh \& Xu, 2001) while alkaline serine proteases produced by $V$. alginolyticus have been reported to be toxic for Kurama prawns (Penaeus japonicus) (Liu et al., 1997). Although it is premature to speculate on the activities of the toxic ECPs from I7, the symptoms of the disease, including limb tremors and eye stalk withdrawal, suggest a neurotoxic component.

Both serum and blood-cell lysates displayed variable levels of antibacterial activity against I4 and I7. In the case of I $4,91 \cdot 3 \pm 3 \cdot 7 \%$ bacterial survival was found after 30 min incubation with the crab blood-cell lysate, while $61 \cdot 7 \pm 10 \cdot 2 \%$ bacterial survival was observed after incubation with neat whole serum (mean values $\pm \mathrm{SE}, n$ $=3$ ). I7 was more effectively killed by both blood-cell lysates and serum preparations $(0 \cdot 26 \pm 0 \cdot 17 \%$ bacterial survival compared with $4 \cdot 3 \pm 2 \cdot 5 \%$ bacterial survival respectively; mean values $\pm \mathrm{SE}, n=3)$. Notably, with $\mathrm{I}$, and to some extent I4, the blood-cell lysate preparations were particularly active in bacterial killing, taking into account the difference in total protein content between this lysate and serum (the concentration of protein in the blood-cell lysate was about 1000 -fold less concentrated than in serum). The limited killing of I4 by both serum and blood-cell lysates partially explains why it is able to multiply in vivo and cause limited mortality. The nature of this antibacterial activity was not investigated further. However, in a closely related species of crab, the shore crab (Carcinus maenas), Schnapp et al. (1996) identified four proteins with antimicrobial activity that reside in the blood cells. In the shrimp, Pennaeus vannamei, a new family of antimicrobial peptides, termed penaeidins, have also been reported to be located in certain blood-cell types (Destoumieux et al., 1997). Although there have been reports of serum antibacterial activity in crabs (e.g. Noga et al., 1994) the extreme fragility of their blood cells suggests that some or all of the serum killing factors may be derived from the haemocytes by degranulation following bleeding.

In conclusion, shell disease is not a disease caused by a single pathogen and should not be considered a disease solely restricted to the exoskeleton. Numerous bacteria within the marine environment are capable of degradation of the chitin component of the crustacean cuticle and it is likely that the collective effects of the lesion community lead to further exoskeletal degradation. If breach of the cuticle occurs, infection of the body cavity of the crustacean may result, with the internal symptoms differing depending on the nature of the penetrating bacteria and this may ultimately lead to the death of the animal.

\section{ACKNOWLEDGEMENTS}

We are grateful to Messrs Paul Llewellyn, Paul Jenkins and Wyn Morris for their assistance with crab collection and to the 
DRIM laboratories, Montpellier, France, for stains of $V$. alginolyticus and V. splendidus. We also thank Dr M. R. Fordy for assistance with the SEM studies. C.L.V. was supported by a University of Wales Swansea studentship.

\section{REFERENCES}

Ayres, P. A. \& Edwards, E. (1982). Notes on the distribution of 'black spot' shell disease in crustacean fisheries. Chem Ecol 1, 125-130.

Baross, J. A. \& Tester, P. A. (1978). Incidence, microscopy, and etiology of exoskeletal lesions in the tanner crab, Chionoecetes tanneri. J Fish Res Board Can 35, 1141-1149.

Brimacombe, J. S. \& Webber, J. M. (1964). Mucopolysaccharides. Amsterdam: Elsevier.

Cerdà-Cuéllar, M., Jofre, J. \& Blanch, A. R. (2000). A selective medium and a specific probe for detection of Vibrio vulnificus. Appl Environ Microbiol 66, 855-859.

Chisholm, J. R. S. \& Smith, V. J. (1992). Antibacterial activity in the haemocytes of the shore crab, Carcinus maenas. J Mar Biol Assoc UK 72, 529-542.

Cipriani, G. R., Wheeler, R. S. \& Sizemore, R. K. (1980). Characterization of brown spot disease of Gulf Coast shrimp. J Invertebr Pathol 36, 255-263.

dal Soglio, F. K., Bertagnolli, B. L., Sinclair, J. B., Yu, G. Y. \& Eastburn, D. M. (1998). Production of chitinolytic enzymes and endoglucanase in the soybean rhizosphere in the presence of Trichoderma harzianum and Rhizoctonia solani. Biol Control 12, 111-117.

Delves-Broughton, J. \& Poupard, C. W. (1976). Disease problems of prawns in recirculation systems in the UK. Aquaculture 7, 201-217.

Destoumieux, D., Bulet, P., Loew, D., Van Dorsselaer, A., Rodriguez, J. \& Bachère, E. (1997). Penaeidins, a new family of antimicrobial peptides isolated from the shrimp Penaeus vannamei (Decapoda). J Biol Chem 272, 28398-28406.

Dietrich, M. A., Hackney, C. R. \& Grodner, R. M. (1984). Factors affecting the adherence of Vibrio cholerae to blue crab (Callinectes sapidus) shell. In Vibrios in the Environment, pp. 601-611. Edited by R. R. Colwell. New York: Wiley.

Dyrynda, E. A. (1998). Shell disease in the common shrimp Crangon crangon: variations within an enclosed estuarine system. Mar Biol 132, 445-452.

Frandberg, E. \& Schnurer, J. (1994). Chitinolytic properties of Bacillus pabuli K1. J Appl Bacteriol 76, 361-367.

Getchell, R. G. (1989). Bacterial shell disease in crustaceans: a review. J Shellfish Res 8, 1-6.

Høi, L. \& Dalsgaard, A. (2000). Evaluation of a simplified semiquantitative protocol for the estimation of Vibrio vulnificus in bathing water using cellobiose-colistin agar: a collaborative study with 13 municipal food controlling units in Denmark. J Microbiol Methods 41, 53-57.

Holt, J. G., Krieg, N. R., Sneath, P. H. A., Staley, J. T. \& Williams, S. T. (1994). Bergey's Manual of Determinative Bacteriology, 9th edn. Baltimore: Williams \& Wilkins.

Hood, M. A. \& Meyers, S. P. (1977). Rates of chitin degradation in an estuarine environment. J Oceanogr Soc Jpn 33, 328-334.

Kang, S. C., Park, S. \& Lee, D. G. (1999). Purification and characterization of a novel chitinase from the entomopathogenic fungus, Metarhizium anisopliae. J Invertebr Pathol 73, 276-281.

Keyhani, N. O. \& Roseman, S. (1999). Physiological aspects of chitin catabolism in marine bacteria. Biochim Biophys Acta 1473, 108-122.

Liu, P. C., Lee, K. K., Tu, C. C. \& Chen, S. N. (1997). Alkaline serine protease is an exotoxin of Vibrio alginolyticus in Kurama prawn, Penaeus japonicus. Curr Microbiol 34, 110-117.

McDougald, D., Rice, S. A., Weichart, D. \& Kjelleberg, S. (1998). Nonculturability: adaptation or debilitation? FEMS Microbiol Ecol 25, 1-9.

Noga, E. J., Engel, D. P., Arroll, T. W., McKenna, S. \& Davidian, M. (1994). Low serum antibacterial activity coincides with increased prevalence of shell disease in blue crabs Callinectes sapidus. Dis Aquat Org 19, 121-128.

Priest, F. G. (1977). Extracellular enzyme synthesis in the genus Bacillus. Bacteriol Rev 41, 711-753.

Prince, D. L., Bayer, R. C., Gallagher, M. L. \& Subramanyam, M. (1995). Reduction of shell disease with an experimental diet in a Nova-Scotian lobster pound. J Shellfish Res 14, 205-207.

Roszak, D. B. \& Colwell, R. R. (1987). Survival strategies of bacteria in the natural environment. Microbiol Rev 51, 365-379.

Sawyer, T. K. (1991). Shell disease in the Atlantic rock crab, Cancer irroratus say, 1817, from the northeastern United States. J Shellfish Res 10, 495-497.

Schlotfeldt, H.-J. (1972). Jahreszeitliche abhangigkeit der 'schwarzfleckenkrankheit' bei der garnele, Crangon crangon (L). Ber Wissen Komm Meeresfors 22, 397-399.

Schnapp, D., Kemp, G. D. \& Smith, V. J. (1996). Purification and characterization of a proline-rich antibacterial peptide, with sequence similarity to bactenecin-7, from the haemocytes of the shore crab, Carcinus maenas. Eur J Biochem 240, 532-539.

Smith, V. J. \& Ratcliffe, N. A. (1980). Host defence reactions in the shore crab, Carcinus maenus (L.): clearance and distribution of test particles. J Mar Biol Assoc U K 60, 89-102.

Smith, V. J. \& Ratcliffe, N. A. (1981). Pathological changes in the nephrocytes of the shore crab, Carcinus maenas, following injection of bacteria. J Invertebr Pathol 38, 113-121.

Smolowitz, R. M., Bullis, R. A. \& Abt, D. A. (1992). Pathological cuticular changes of winter impoundment shell disease preceding and during intermolt in the American lobster, Homarus americanus. Biol Bull 183, 99-112.

Stewart, J. E. (1993). Infectious diseases of marine crustaceans. In Pathobiology of Marine and Estuarine Organisms, pp. 319-342. Edited by J. A. Couch \& J. W. Fournie. Boca Raton: CRC Press.

Sudheesh, P. S. \& Xu, H. S. (2001). Pathogenicity of Vibrio parahaemolyticus in tiger prawn Penaeus monodon fabricius: possible role of extracellular proteases. Aquaculture 196, 37-46.

Tronsmo, A. \& Harman, G. E. (1993). Detection and quantification of $N$-acetyl- $\beta$-D-glucosaminidase, chitobiosidase, and endochitinase in solutions and on gels. Anal Biochem 208, 74-79.

Urakawa, H., Kita-Tsukamoto, K. \& Ohwada, K. (1999). Restriction fragment length polymorphism analysis of psychrophilic and psychrotrophic Vibrio and Photobacterium from the northwestern Pacific Ocean and Otsuchi Bay, Japan. Can J Microbiol 45, 67-76.

Vogan, C. L. \& Rowley, A. F. (2002). Effects of shell disease syndrome on the haemocytes and humoral defences of the edible crab, Cancer pagurus. Aquaculture (in press).

Vogan, C. L., Llewellyn, P. J. \& Rowley, A. F. (1999). Epidemiology and dynamics of shell disease in the edible crab Cancer pagurus: a preliminary study of Langland Bay, Swansea, UK. Dis Aquat Org 35, 81-87.

Vogan, C. L., Costa-Ramos, C. \& Rowley, A. F. (2001). A his- 
tological study of shell disease syndrome in the edible crab, Cancer pagurus. Dis Aquat Org 47, 209-217.

Wardell, J. N. (1988). Methods for the study of bacterial attachment. In Methods in Aquatic Bacteriology, pp. 389-415. Edited by B. Austin. Chichester: Wiley.

Yanai, K., Takaya, N., Kojima, N., Horiuchi, H., Ohta, A. \& Takagi, M. (1992). Purification of 2 chitinases from Rhizopus oligosporus and isolation and sequencing of the encoding genes. J Bacteriol 174, 7398-7406.

Young, J. S. (1991). Prevalence and severity of shell disease among deep-sea red crabs (Chaceon quinquedens, Smith 1879) in relation to ocean dumping of sewage sludge. J Shellfish Res 10, 499-503.

Young, J. S. \& Pearce, J. B. (1975). Shell disease from crabs and lobsters from New York Bight. Mar Pollut Bull 6, 101-105.

Zhang, X. H. \& Austin, B. (2000). Pathogenicity of Vibrio harveyi to salmonids. J Fish Dis 23, 93-102.

Received 16 July 2001; revised 24 October 2001; accepted 12 November 2001. 